\title{
Det digitale interaktive fjernsyn i hverdagslivet
}

\author{
Af Thomas Bjørner
}

Digitaliseringen af tv-mediet er allerede i fuld gang, og der er i Danmark fastlagt en analog slukdato for public servicekanalerne i 2009. I forlangelse heraf leverer denne artikel en rakke indsigter $i$, hvordan den nye teknologi potentielt forandrer hverdagen, men samtidig er det også en pointe, at den digitale teknologi indpasses i eksisterende monstre for tv-sening. Med baggrund i forsogskanalen TV2/NordDigital, som var den forste kanal der udsendte digitalt interaktivt tv $i$ Danmark, vil denne artikel give nogle svar på, hvad der sker når digitalt to (med de ogede interaktive muligheder) vinder indpas $i$ husstanden. Hvem skal bestemme i forhold til hvad der skal ses af interaktivt indhold? Vil digitaliseringen dermed fremme den stigende tendens til at vi ser mere to hver for sig?? Og onsker seerne overhovedet at vare interaktive med deres fjernsyn - og i givet fald om hoad og hvorfor?

I Danmark er det politisk besluttet, at public service broadcasterne DR og TV 2/Danmark bygger og driver de forste digitale kanaler free-to-air (dvs. ukrypteret), udsendt via sendemaster i den såkaldte DTT (Digital Terrestrisk TV) distribution. ${ }^{1}$ Public service broadcasterne har hermed fået tildelt rollen som første skridt i den digitale overgang, hvor det politisk er besluttet at slukke for det analoge tvsendenet med udgangen af oktober 2009. Pr. 31. marts 2006 var det således muligt for alle danskere at modtage digitalt terrestrisk tv, indeholdende kanalerne DR1, DR2, TV2 og TV2's regionale tv-stationer. Med digitaliseringen skabes dels bedre billede- og lydkvalitet, men også muligheder for en række interaktive tjenester. Således er det allerede muligt for de som ser digitalt terrestrisk tv at få simultan tegnsprogstolkning til nyhedsudsendelser samt adgang til en elektronisk programguide. Men de øgede valgmuligheder kunne også være andre former for interaktive tjenester, som f.eks. søge bolig og benytte e-mails via fjernsynet, fremkalde madopskrifterne på tv-skærmen ved diverse madprogrammer, fremkalde ekstra informationer i forbindelse med nyhederne, gætte med i diverse quizzer, blive fri for reklamerne eller som seer selv vælge kameravinklerne.

Formålet med denne artikel er, at give nogle indsigter i forbindelsen mellem hverdagsliv og teknologi. Artiklen giver således nogle svar på hvad der sker når digitalt terrestrisk tv (med de øgede interaktive muligheder) vinder indpas i husstanden. Hvem skal bestemme i forhold til hvad der skal ses af interaktivt indhold, og vil digitaliseringen dermed fremme den stigende tendens til at vi ser mere tv hver for sig? Onsker seerne overhovedet at være interaktive med deres fjernsyn - og i givet fald om hvad og hvorfor? Svarene på disse spørgsmål synes dels at være, at de vaner seerne havde i forhold til det gamle analoge tv overføres til det nye digitale tv-medie, og dels at seerne efterspørger tjenester, der kan bryde det traditionelle analoge tv-flow i flere individuelle valg. Men som artiklen også giver indsigt i, så er forholdet mellem hverdagsliv og teknologien en ret kompleks størrelse, fordi tv anvendes på forskellige måder af seerne.

Baggrunden for artiklen er forsøgskanalen TV2/Nord-Digital, hvorfra jeg i forbindelse med min ph.d. afhandling havde indsamlet et omfattende forskningsmæssigt empirisk materiale i en kombination af både kvalitative- og kvantitative data. ${ }^{2}$ TV2/Nord-Digital var en forsøgskanal under Det Digitale Nordjylland. ${ }^{3}$ Den sendte i perioden fra november 2002 til oktober 2004, og var første kanal som udsendte digitalt terrestrisk tv i Danmark. TV2/Nord-Digital var derfor interessant som forskningsobjekt på flere måder. For det første fordi det var den første egentlige digitale tvkanal i Danmark, der ved opstarten i 2002 havde 
store planer om en lang række interaktive tjenester og en konvergens mellem pc og tv. For det andet kunne TV2/Nord-Digital ses som en forløber for, hvad den landsdækkende digitale sending fra 31. marts 2006 kom til at indeholde.

\section{Forskningsoversigt}

Test-piloterne til TV2/Nord-Digital var selvvalgte, hvor hvervningen skete gennem reklamespots hos TV2/Nord, og interesserede kunne således tilmelde sig via internettet. Det digitale testforsøg var inddelt $i$ tre perioder, med udskiftning af testpiloter i hver periode. Der var kun foretaget forskning på de to første perioder (fra november 2002 til marts 2004), hvor der deltog 277 husstande i 1. periode og 249 husstande i 2. periode. Jeg havde anvendt en tværmetodisk og tværteoretisk tilgang, der trak både på kvalitative- og kvantitative metoder. I et kvalitativt mediesociologisk mikroperspektiv blev der interviewet 15 udpegede husstande (udvalgt på baggrund af alder, antal medlemmer i husstanden og geografisk placering ${ }^{4}$ ) over to omgange med et års mellemrum. På mange måder lignede min metodiske tilgang den som David Morley benyttede i hans klassiske bog »Family Television« (Morley, 1986). Morley tog udgangspunkt i, at folks seermønstre kun kan forstås i sammenhæng med familiens hverdagsliv og fritidsliv. Han lagde vægt på, hvordan familiernes interaktionsform og rollefordeling fungerede igennem diskussionen af tv-brugen (Morley, 1986, s. 52). I min undersøgelse talte jeg med de 15 udpegede husstande to gange $i$ et arrangeret interview af 2-3 timers varighed, med lignende interviewmetode som Morley. Jeg anvendte en ustruktureret diskussion hvor jeg dog spillede den vigtigste rolle som moderator.

Brugerundersøgelser er forskningsmæssigt forholdsvist velbeskrevet inden for interaktivt tv. Herunder kan opregnes en række kvantitative forskningsresultater af, hvordan brugerne havde taget digitalt tv til sig (Higgins, 2000; Mackay, 2002; Theodoropoulou, 2003). Der findes også en række medieetnografiske studier af interaktivt tv (O’ Brien et al., 1999; Rasmussen, 2002; HelleValle \& Stø, 2002; Eronen 2005). Fælles for de tidligere tilgange er, at de har haft et fokus på brug og oplevelse af interaktivt tv som hardware. Derimod har der ikke været et større fokus på brug og oplevelse af den interaktive tekst/ tekstoplevelsen i hjemmet, der hvor mediebrugen faktisk finder sted. Jeg har derfor i mine kvalitative interview ikke kun fokuseret på den sociale brug af det nye digitale medie som hardware, men i høj grad spurgt ind til tekstoplevelsen af de forskellige interaktive tjenester.

\section{Prasentation af TV2/Nord-Digital}

I forbindelse med det digitale tv-forsøg kunne test-piloterne modtage digitalt tv fra DR1, DR2, TV2 og TV2/Nord-Digital. På TV2/Nord-Digital kunne test-piloterne også se programmer med ekstra informationer (markedsført som »digital merværdi«), der bestod i en tekstbaseret service, som kunne være med til at understøtte et program indholdsmæssigt. Servicen kunne f.eks. bestå i ekstra informationer om de medvirkende i programmet eller opskrifterne til retterne i et madprogram. Det var i det første år af forsøget kun muligt at fremkalde disse ekstra informationer, mens udsendelsen var i gang, men blev derefter ændret, således at der blev lavet en såkaldt akkumuleret merværdi (tidsuafhængigt af det enkelte program). Her var det muligt at hente samtlige opskrifter fra udsendelserne Slank Igen og havetips fra udsendelserne Det gronne rejsehold.

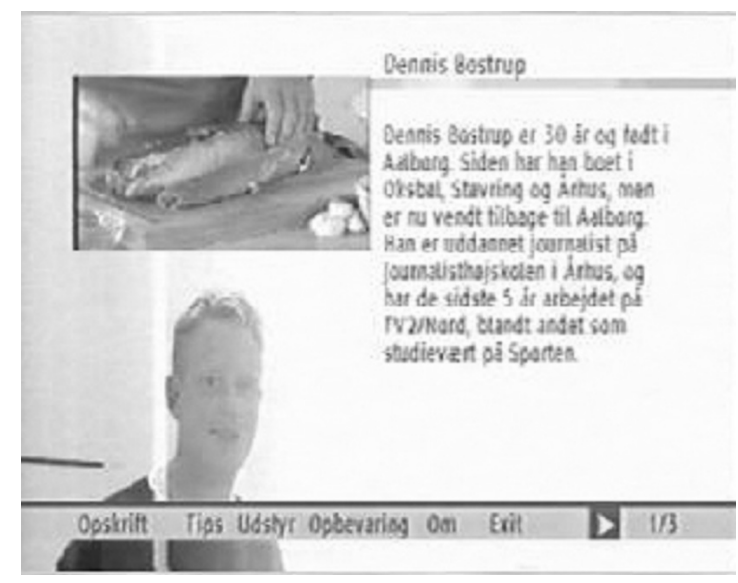

Eksempel på ekstra information fra TV2/NordDigital. Her fra programmet Slank Igen som var et mad- og motionsprogram med opskrifter til slankemad og motionsråd. Ved tryk på »ok-knappen« på fjernbetjeningen kommer menu-linjen frem i bunden af billedet. En tekst-baseret del i højre side af skærmen. Øverst til venstre det audiovisuelle udtryk, og nederst til venstre et still-billede. 
Derudover blev der undervejs i forsøget opbygget en elektronisk programguide (EPG) og portal med nyheder fra Ritzaus Bureau. Desuden kunne brugerne mod slutningen af forsøget etablere en returvej (via telefonlinien), hvor de kunne skrive e-mails via deres tv (det var dog ikke muligt at vedhæfte filer). Selve skrivningen af teksten foregik via fjernbetjeningen, hvor bogstaverne skulle tastes frem som ved SMS på mobiltelefonen. Endelig blev det muligt at se internetsider, hvilket dog begrænsede sig til to sider på internettet (Told- Skat og IT \& Telestyrelsens hjemmesider) grundet formatmæssige barrierer, idet siderne skulle være skrevet i xhtml-standarden. Udover de allerede nævnte tjenester blev der opbygget en enkelt tjeneste med kommercielt sigte. Det drejede sig om ejendomsmæglerkæden Homes boligsøgning, hvor seerne selv kunne vælge, om og hvornår de ønskede at gå ind i denne reklamefinansierede del og søge efter boliger i regionen. Returvejen var gennem telefonnettet. Derudover var der planer om opbygning af en såkaldt »markedsplads«, hvor det fra sendestarten var tanken, at seerne kunne finde dagens eller ugens tilbud. I første omgang var det tiltænkt erhvervskunder hos Nordea som et alternativ til internettets muligheder. Homes boligapplikation eksisterede kun i meget kort tid (ca. to måneder), og markedspladen blev aldrig opbygget, primært på grund af teknologiske hindringer og returvejsproblemer, men også en manglende analyse af om seerne faktisk ønskede disse tjenester via fjernsynet.

\section{Eksempel fra \\ Home's boligapplikation, TV2/Nord-Digital}

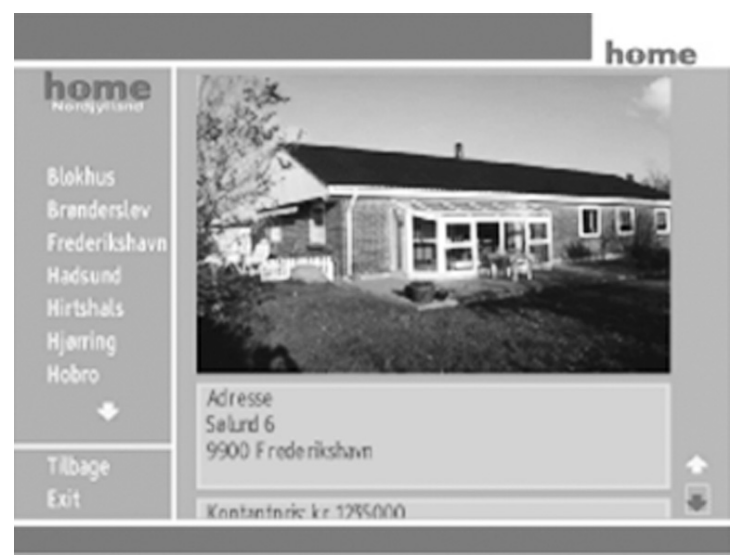

\section{Størrelsen og designet har betydning}

Fjernsynet er kendetegnet ved en enorm udbredelse, og er ikke blot et teknologisk apparat, men er også et socialt og kulturelt fænomen. Der er derfor ingen tvivl om, at tv-sening i hjemmet er mere end blot receptionen af audiovisuelle programmer, men er en vane, som er indlejret i hverdagslivets kontekst. Derfor er det også nødvendigt at se på interaktivt tv som et socialt og kulturelt fænomen. Måden vi ser tv på afhænger også af teknologien og designet for tv-apparaterne. Op gennem tv-mediets historie (fra starten af 1930'erne og frem til i dag) er der blandt andet kommet større skærme. Det store spring kom i slutningen af 1950'erne, hvor seerne kunne gå fra 14" til 20" tv og dermed også fik mulighed for større distance til tv-apparatet, og frem til i dag hvor store fladskærme vinder frem. Erfaringer fra TV2/Nord-Digital forsøget viste, at interaktivt tv også er et skærmfladespørgsmål, hvor en større skærm gjorde det nemmere for seerne at læse de ekstra informationer og samtidig følge det audiovisuelle udtryk. Der var således også flere eksempler på, at test-piloterne under TV2/ Nord-Digital forsøget havde købt et større tv for derved bedre at kunne multitaske - og se både en ekstra information (f.eks. en madopskrift) og det audiovisuelle udtryk samtidig:

»Det kan godt være det er mig der er lidt halvblind. Jeg ved ikke lige hvordan man kan lave interaktivitet, så man bevarer selve tv-skærmbilledet lidt større...man kan ikke rigtig følge udsendelsen imens. Det skulle egentlig være sådan, at i stedet for du følger udsendelsen... så sidder du lige og læser og supplerer dig ikke« (Husstandsinterview 1. runde: Husstand 10: P = Mand 43 år)

Der er sket en meget stor stigning i antallet af tvapparater i de danske hjem. Således har 47,2\% af alle danske husstande mere end ét tv-apparat i hjemmet i dag, mod ca. 9 \% i 1980 (Gallup, 2004). Det skyldes dels, at fjernsynet er blevet billigere og dels et stærkt stigende kanaludbud. Alene fra 2000 til 2004 stiger antallet af tv-husstande med 31 eller flere indstillede kanaler fra $5 \%$ til $19 \%$ (Gallup, 2004). Alle erfaringer fra både England og Danmark viser, at seerne ikke vælger digitalt tv pga. de interaktive tjenester, men at dette valg snarere er begrundet i muligheden for et større kanaludbud og for bedre billed- og lydkvalitet 
(Oftel, 2001; Theodoropoulou, 2003; TDC, 2003; Looms, 2004). Dette fremgår da også af de reklame fremstød, som Viasat og Canal Digital gør for deres set-top-bokse, hvor de netop slår på det øgede kanaludbud som fordelen ved digitalt tv. Danskernes samlede gennemsnitlige tv-sening er steget 12 minutter fra 2 timer og 30 minutter $i$ 2000 til 2 timer og 42 minutter i 2004. Blandt alle seere (3 år +), foregår 72 \% af den samlede tv-tid dog på danske public service stationer DR1, DR2, TV2 og TV2 Zulu (Gallup, 2004). Så selvom danskerne har adgang til mange forskellige kanaler, så fordeler seer-andelene sig i overvejende grad over nogle få danske public service kanaler. Heri kan man finde en af årsagerne til, at danskere ikke har taget interaktivt tv til sig i nævneværdig grad. Således er der reelt ikke brug for f.eks. en EPG (Elektronisk Program Guide) til at navigere rundt i de mange kanaler. Hertil kommer, at danskerne også i høj grad bruger tekst-tv til at overskue programoversigter. $71 \%$ (rating) ser ugentligt DR's programoversigt på siderne $300-305^{5}$ (DR Medieforskningen, 1. halvår 2005).

Næsten alle danske husstande (98,4\%) havde i 2004 placeret mindst ét tv i dagligstuen (Gallup, 2004). I forbindelse med TV2/Nord-Digital forsøget var det også karakteristisk at set-top-boks og eventuel stueantenne (som var nødvendigt for at kunne modtage det jordbaserede digitale signal) primært var placeret i dagligstuen. Set-top-boksen var kun en anelse mindre end en almindelig videomaskine, og skulle placeres i nærheden af det fjernsyn, hvortil man ønskede digitalt tv, hvorfor det kun var muligt at se TV2/Nord-Digital (indeholdende de interaktive tjenester) på ét fjernsyn i hjemmet. Derfor måtte familierne træffe et valg inden installationen, nemlig hvor Set-top-boksen skulle placeres. ${ }^{6}$ Dette er i øvrigt et stort generelt problem for digitalt $\mathrm{tv}$, at de installerede set-topbokse kun kan opsættes til ét enkelt tv-apparat. Med tiden vil dette tekniske problem sikket blive løst, men for nuværende er det et irritationsmoment for seerne.

Den æstetiske dimension i forhold til den eventuelle tilknyttede stueantenne viste sig at være overordentlig vigtig i forhold til forbruget af det digitale interaktive tv. Fordi TV2/Nord-Digital udsendtes via et terrestrisk sendenet, behøvede den enkelte husstand en fællesantenne eller stueantenne for at kunne modtage signal. Mange husstande, specielt i større urbane områder, var tilsluttet kabel, hvorfor man fra TV2/Nord-Digital stillede stueantenner gratis til rådighed sammen med set-top-boksen til disse familier. Imidlertid var stueantennen særlig udskældt - specielt af kvinderne, fordi den ikke "pyntede i stuen". Ud fra kvindernes æstetiske overvejelser, om hvad der var pænt/ ikke pænt i stuen, havde manden i nogle familier været "nødsaget" til at placere set-top-boksen og stueantennen $i$ andre rum end i dagligstuen:

"Jeg har jo ikke set noget af det der fjernsyn overhovedet (TV2/Nord-Digital). Ah jeg har måske set lidt, hvis jeg lige har været nede på hans kontor med en kop kaffe". (Husstandsinterview 1. runde: Husstand 12: $\mathrm{H}=$ Kvinde 59 år)

"Du har jo nok set de stueantenner, så den får ikke lov at stå i stuen. Jeg vil ikke engang selv have den til at stå der...jeg vidste hvad hun ville sige, hvis den skulle stå i stuen". (Husstandsinterview 1. runde: Husstand 12: M = Mand 55 år)

I denne familie havde man således valgt at placere set-top-boksen og stueantennen i forlængelse af mandens fjernsyn på "hans kontor". Dette vidner om hans brug af fjernsynet som meget ekstensivt, hvor han kunne arbejde samtidig eller dreje sig rundt, hvis han hørte noget vigtigt. Set-top-boksen blev på denne måde gemt lidt af vejen i forhold til, når familien havde gæster, eller når ægteparret i øvrigt opholdte sig i stuen. Som citatet også vidner om, havde familien reflekteret over hjemmets æstetiske udtryk og havde derfor besluttet, at set-top-boksen i hvert fald ikke skulle stå i stuen. Tilsyneladende havde kvinden i hjemmet også haft den afgørende rolle i forhold til hjemmets æstetiske indretning, herunder hvor set-top-boksen og stueantenne skulle placeres. Grundet at set-top-boksen stod på mandens kontor, bevirkede det også, at forbruget af TV2/Nord-Digital næsten udelukkende sorterede under ham, for som kvinden i hjemmet udtrykte det, så "har hun ikke set noget overhovedet".

Dette afsnits kontekstuelle overblik, har vist hvordan danskernes generelle brug af tv skal ses i sammenhæng med digitalt interaktivt tv. Det fremgår også hvordan interaktivt tv er et spørgsmål om æstetik i forhold til størrelsen på skærmen og designet af stueantennen. Jeg ønsker nu at indkredse den sociale dimension nærmere, og fokusere på 
hvad gruppesening har af konsekvenser for brugen af interaktivt tv.

\section{Det er egoist tv}

Generelt går gruppesening (det at flere ser samme tv-program samtidigt i husstanden) tilbage til fordel for solosening. I 2002 tegnede gruppesening sig for $40 \%$ af al sening i forhold til $55 \%$ i 1992 (Looms, 2004, s. 124). Men i de tilfælde, hvor der er tale om programmer udover det sædvanlige (dansk drama som Kroniken og Rejseholdet eller sport som EM fodbold med dansk deltagelse) er oplevelsens vigtighed så stor, at mange laver om på sociale aftaler for at sikre sig, at "magic moments" (Looms, 2004, s. 124) ikke forstyrres. Her er der således tale om planlagt sening. Men tv-mediets force (i modsætning til f.eks. en avis), er også at det "byder sig direkte til som fælles reference og muligt samtaleobjekt i receptionskonteksten" (Rasmussen, 2002). Altså er det muligt at samtale om tv-teksten med andre seere i stuen i et her-ognu-forhold, således at "ytringer med reference til medieteksten indgår i den daglige forhandling af mig, familien og verden...i et situeret praksisfællesskab" (Rasmussen, 2002). Det situerede praksisfællesskab omkring tv-seningen făr dog en ganske særlig betydning, når det drejer sig om interaktivt tv. Ekstra informationerne på tv-skærmen kræver en vis enighed ved gruppesening om, hvad man vil se og hvornår. Problemet ved det digitale tv er, at det kun kan tilsluttes til ét tv-apparat, og derfor er forhandlingerne om tv-brugen ved interaktivt tv anderledes end ved almindeligt programvalg, fordi det ikke kan indgå i forhandlingerne, at hvis man ønsker at se noget andet, bare kan benytte andre fjernsyn i hjemmet. Ved brug af interaktive tjenester er den person, der ikke har fjernbetjeningen derfor blevet hensat til at være observatør, mens den person der har fjernbetjeningen navigerer. Seere med observatør-rollen kan således potentielt gå glip af de ekstra informationer, hvor de ikke făr det hele med. Fra spørgeskemaundersøgelserne i TV2/Nord-Digital forsøget fremgik det, at ekstra informationerne anvendtes i langt højere grad, når brugerne sad alene, frem for når seerne sad flere og så det samme, som er beskrevet andre steder (Bjørner, 2005, s. 95). Når flere seere læser teksten på samme tid i ekstra informationerne, opstår også et problem i forhold til forskellige læsehastigheder:
"Jo, det (at have gået glip af merværdien) har jeg vel egentlig også oplevet, fordi du er hurtigere til at læse måske end jeg” (Husstandsinterview 3. runde. Husstand 2: Kvinde 46 år).

Kvinden var gået glip af dele af den digitale merværdis tekst, fordi manden navigerede rundt i menuen uden bevidst eller ubevidst at tage hensyn til, om hun havde læst al teksten. Som det fremgår ud fra ovenstående udtalelse, herskede der en lettere forvirring eller kaos, blot der skulle læses i ekstra informationerne kollektivt. Selve forhandlingerne i sig selv skaber konflikt, og derudover kan tekstforståelsen i den digitale merværdi potentielt gå tabt.

"Jo det er en konflikt der sker. Kim han trykker på alle de taster, og jeg vil overhovedet ikke have tekst på...jamen altså, jeg vil jo ikke se teksten, og Kim han vil".

(Husstandsinterview 3. runde. Husstand 2: Kvinde 46 år).

"Det er nemmere, når man sidder alene. Så kan man gå ind i det, når man vil...Vi sad og råbte lidt af hinanden (griner)". (Husstandsinterview 3. runde. Husstand 1: Mand 26 år).

Som det fremgår af citaterne, er der uenighed om, hvorvidt der overhovedet skal læses i ekstra informationerne "jamen altså, jeg vil jo ikke se teksten, og Kim han vil". Den kollektive tilegnelse af TV2/Nord-Digital vidner dermed om en række problemer, idet der opstår modstridende ønsker, om det overhovedet skal være interaktivt under udsendelsen. Det er via fjernbetjeningen der navigeres rundt i den digitale merværdi. Der kan derfor til tider udvikles uoverensstemmelser om, hvem der skal styre set-top-boksen og menuen via fjernbetjeningen:

»Det er jo ikke sikkert man har samme interesse i det...man gider ikke at læse de samme menuer og sådan nogle ting...så kan der godt lige blive lidt bøvl om det at styre fjernbetjeningen...jeg tror sgu bare det er den der er nærmest fjernbetjeningen, der får lov til at styre«. (Husstandsinterview 3. runde: Husstand 1: Mand 26 år).

Det sker ikke altid, at alle seere får lige megen glæde af merværdiens funktioner, og generelt er det bare den, der er nærmest fjernbetjeningen, som får lov at styre, indtil forhandlingerne eventuelt bryder sammen, og den kollektive læsning af ekstra infor- 
mationerne må opgives. Forhandlingerne er ifølge en række af seerne på forhånd dømt til at bryde sammen, fordi:

"Det er egoist-tv...fordi man ikke kan ikke blive enige om, hvilke sider man skal se". (Husstandsinterview 3. runde: Husstand 2: Mand 48 år).

Overordnet set skaber TV2/Nord-Digital altså i høj grad kontrolproblemer inden for hjemmet, hvilket har en direkte indflydelse på den måde (socialt og kulturelt) der ses digitalt interaktivt tv på.

Dette afsnit fokuserede på hvad der sker med mediebrugen i hjemmet, når tv-mediet bliver digitalt, og hvilke problemer der opstår i forhold til hvem der skal bestemme i forhold til de øgede valgmuligheder. Eksemplerne som er nævnt i dette afsnit var i forhold til nogle interaktive tjenester, som seerne ikke selv havde valgt i forhold til deres interesser, men hvad der tilfældigvis var af udbud af interaktivt indhold på interviewtidspunktet. Dette gav naturligvis en lidt kunstig situation, men resultaterne giver alligevel et fingerpeg om nogle af de problemer der kan opstå ved gruppesening af interaktivt tv. Min undersøgelse havde derfor også spurgt seerne, hvilke af samtlige interaktive tjenester de kunne tænke sig at gøre brug af, hvis de var mulige. I modsætning til en lang række surveyundersøgelser i forhold til hot og not af interaktive tv-tjenester (Oftel, 2001; Theodoropoulou, 2003; Jennings, 2004), har jeg meget bevidst brugt den kvalitative metode til at spørge nærmere ind til baggrunden for, hvorfor noget er hot og not af interaktive tjenester.

\section{Hot og Not af interaktive tv-tjenester}

I forbindelse med TV2/Nord-Digital forsøgt blev de interaktive tv-brugere spurgt, hvilke former for interaktive tjenester de kunne tænke sig. Det er særligt udfordrende for producenter af interaktivt tv at ramme seernes behov for dette nye digitale medie. Det er også forskningsmæssigt vanskeligt at beskæftige med seernes ønsker, idet medieteknologierne stadig er under forandring, og det samme er tv-seeren. Det vanskelige består således i at spørge nutidens tv-seer om fremtiden tv-vaner, og det kan derfor være svært at se fremtiden i fremtidens perspektiv, men oftest tolkes fremtiden i nutidens optik, hvilket ville svare til at spørge min gamle bedstefar i 1951, hvordan han kunne se fremtidens tv foran sig. Test-piloterne til TV2/Nord-Digital fandt, at den interaktive tjeneste de bedst kunne tænke sig, var en tjeneste der kunne springe reklamerne over midt i en udsendelse. Spørgsmålet omkring dét at kunne springe reklamerne over er afledt af introduktionen til den personlige video (en såkaldt PVR, Personal Video Recorder), der har en stor udbredelse i USA og Japan. En PVR er en digital video, der kan lagre programmer på harddisken, så seeren kan afspille dem efter eget behov. Dette kræver ikke en egentlig set-top-boks hos seerne, men kan dog være indbygget i Set-topboksen eller DVD'en. Fra husstandsinterviewene fremgår det at flere af husstandene bruger videoen som en slags PVR. Særligt når det gælder TV3 og 3+:

"Ja, det er godt nok træls. Jeg ser efterhånden ikke ret meget TV3 og 3+, fordi jeg synes det er blevet lange alle de reklamepauser der er inde midt i... Ellers så gør jeg det, at så optager jeg de kanaler, og så spoler jeg hen over reklamerne" (Husstandsinterview 2 runde: Husstand 3: J = Mand, 29 år).

Det fremgår også af min undersøgelse, at seerne havde en stor interesse for at vælge mellem forskellige kameravinkler. Når seerne kommer ind på det at skifte kameravinkler, nævnes oftest eksempler fra sportsgenren. Men seerne angiver også et dilemma mellem dét selv at kunne skifte kameravinkler og samtidig bevare overblikket. Således angiver flere af seernes, at hvis de f.eks. selv kunne vælge kameravinkler i fodbold, og fokuserer på en enkelt spiller, samtidig mister overblikket over banen. Dette hænger naturligt sammen med fodboldspillets form, hvor den enkelte spiller ikke er i fokus hele tiden. Derudover kan overblikket mistes i nogle sportsgrene med hurtige skift (f.eks. fodbold og håndbold), fordi seerne ikke kan foretage kameraskiftene bedre og hurtigere end den professionelle producer, mens det at være egen kameraproducer kunne være mere anvendeligt $\mathrm{i}$ andre sportsgrene med få skift og fokus på den enkelte sportsudøver (f.eks. golf).

Quiz-genren synes også at være særlig populær i forhold til, hvad seerne har stor interesse for af interaktive tjenester. Det gælder både en 'gætten med' i quizzen Hvem vil vare millioner (som sendes på TV2) og boligquizzen Hammerslag (som sendtes på DR1). Quiz-genren kan byde sig forførende 
til med udfordrende spørgsmål - og hvor man hjemme i stuerne ikke kan lade være med at gætte med, eller som den litterære kulturforsker Martin Zerlang beskriver det: »TV-apparatet har placeret sig i hjertet af denne selskabelige sfære. Det er blevet det sted, som samler alle følelser og forventninger i det kaminvarme fællesskab. Her finder man brændpunktet for den moderne, daglige selskabelighed. Det kan derfor ikke overraske, at det nye medium har taget de gamle selskabslege som indhold « (Zerlang, 1991, s. 237). I forhold hertil er samtidighed særlig vigtig - også for brugen af en mulig interaktiv tjeneste. Det må foregå her-og-nu i en tidsafhængig interaktivitet, hvis det skal være muligt via fjernbetjeningen at lege med i quizzen. Det fremgår af de kvalitative interview fra TV2/Nord-Digital, at den interaktive quiz også skal have en umiddelbarhed, som giver seerne en fornemmelse af at være deltagere og ikke kun iagttagere. Det synes ikke at være afgørende at seerne kan vinde store præmier, blot de kan føle samme hæder blandt øvrige familiemedlemmer, som aktørerne på skærmen - uden man dog taber det helt store. I de senere år har man set et væld af afstemninger og konkurrencer i forbindelse med quiz-programmer på dansk tv, men hvor returvejen etableres via mobiltelefonen og SMS. Det fremgår således ud fra udtalelserne fra en gruppe af interviewpersonerne, at de mener, at den ældre målgruppe af seere kunne deltage i større udstrækning, hvis returvejen til quiz-programmer blev gjort via fjernbetjeningen og set-top-boksen.

Ser man derimod på hvilke interaktive tjenester seerne slet ikke udviser interesse for, omfatter det bl.a. muligheden for at kunne vælge imellem slutninger på film. Her er seernes argument, at selve ideen med filmen går tabt, hvis de selv skal vælge imellem forskellige slutninger, idet filmen er instruktørens værk og ikke seernes. Der er også en overvægt af seere, der ikke ønsker bankoverførsler, boligsøgning og e-mail via fjernsynet. Flere af seerne angiver, at det er et forstyrrende element at skulle bruge fjernsynet som e-mail eller bankoverførsler, fordi det giver problemer med, hvornår de skal gå ind i forhold til programflowet - før eller efter programmerne. Eller som en meget teknologistærk husstand sagde det:

»Jeg kan ikke forestille mig situationer, hvor forældrene så sidder der, og de skal lige ordne deres bankoplysninger, og børnene skriger fordi de vil se Disney Sjov. Det setup kan jeg ikke lide« (Husstandsinterview 2: Husstand 7: $\mathrm{S}=$ Mand 29 år).

Der var under hele forsøgsperioden ingen af testpiloterne, der etablerede returvejen med adgang til bl.a. e-mails og boligsøgning, idet set-top-boksen fra TV2/Nord-Digital forsøget ikke var tilstrækkelig udviklet (herunder manglende harddisk) til at gøre interaktiviteten tilstrækkelig attraktiv for brugerne. Derudover havde stort set samtlige testpiloter adgang til computer/ internet (svarende til $98 \%$ ), og de brugte således computeren til e-mail og eventuel boligsøgning, idet computeren både var væsentlig hurtigere, mere funktionsvenlig og informationsrig. Målet om at TV2/Nord-Digital via det digitale terrestriske sendenet skulle skabe "fremtidens digitale elektroniske informationscenter« (TV2/Nord-Digital Statusrapport, efteråret 2004) lykkedes derfor ikke.

De skitserede interaktive tjenester af hvad der er hot og not, kan fordeles på to forskellige niveauer. Dels i forhold til nogle tjenester som seerne kan vælge til og fra (f.eks. reklamer og ekstra informationer), og dels nogle særlige genrer som rummer nogle digitale muligheder og kvaliteter for seerne (f.eks. sport og quiz-genren). Men resultaterne bør anskues på et højere niveau, og kan med fordel typologiseres forskelligt. På et indholdsmæssigt plan skelner den engelske medieforsker Vivi Theodoropoulou mellem kontekstuelle og non-kontekstuelle interaktive tjenester (Theodoropoulou, 2003, s. 292), hvor hun kalder tjenester der fungerer udenfor selve tv-konteksten, uafhængigt af tv-flowet for non-kontekstuelle og nævner herunder tv-banking shopping, e-mailing og spil m.v. De kontekstuelle tjenester derimod er indlejret i selve tv-indholdet, $\mathrm{og}$ forstyrrer ikke flowet eller seningen, hvor seerne stadig kan se udsendelsen i et mindre vindue. Min undersøgelse viser således, at de non-kontekstuelle tjenester ikke synes at tiltrække seerne i samme grad som de kontekstuelle, der er mere populære. Lignende resultat finder man i øvrigt også hos Theodoropoulou (Theodoropoulou, 2003, s. 292) og Forrester Research (Jennings, 2004, s. 3). 


\section{Digitalt tv og forandringer i hverdagslivet}

Digitaliseringen af tv-mediet er allerede i fuld gang, og der er fastlagt en analog slukdato for public servicekanalerne i 2009. Det er derfor interessant forskningsmæssigt at se på hvilke forandringer der kan ske i hverdagslivet på baggrund af digitaliseringens interaktive muligheder. Analogt tv og digitalt interaktivt tv har både nogle fællestræk og nogle særegne karakteristika og bruges derfor både socialt ens og forskelligt i hjemmet. Når testpiloterne i TV2/Nord-Digital forsøget svarede på, hvad de havde af interesse i fremtidens tv, var der ingen tvivl om, at de så fremtidens tv i nutidens perspektiv, og svarede på om de kunne tænke sig forskellige interaktive tjenester set $\mathrm{i}$ forhold til hvordan deres hverdagsmæssige mediebrug var i dag. Seernes interesser vidner om en meget kompleks forståelse af brugen af fjernsynet, og der findes store variationer i forhold til forskellige typer af interaktive programmer, men også en stor variation $\mathrm{i}$ forhold til forskellige typer af seere. Det væsentligste synes at være, at seerne ønsker at kunne bryde det traditionelle analoge tv-medies flow med mere individuelle muligheder, f.eks. at se uddybende information om præcis den nyhed i TV-Avisen, som den enkelte seer er mest interesseret i, at blive fri for reklamepauserne på TV3 eller selv vælge kameravinklerne. Set fra broadcasternes perspektiv kunne man således forestille sig, at de kunne fastholde seerne i større udstrækning via flere valgmuligheder, idet seerne individuelt vælger i forhold til egne interesser og ikke keder sig som følge af det forudbestemte flow. Således kan digitalt interaktivt tv opfylde et behov hos seerne, idet det kan give dem en mere dynamisk brug $\mathrm{i}$ forhold til analogt tv. Af særlig stor interesse hos seerne blandt digitale interaktive tjenester synes at være tjenester, der kan karakteriseres som pushtjenester. Det er tjenester, hvor informationen kommer til seeren (fra broadcasteren), men som for den enkelte seer kan opleves som pull-tjenester, hvor de føler de selv vælger hvilken information de ønsker at modtage. Derimod synes en række interaktive tjenester som pull-tjenester i mindre grad at tiltrække seerne. Dette gælder f.eks. boligsøgning eller bankoverførsler via tv-mediet. Det analoge tv har også nogle fordele - hvor man kan læne sig tilbage, og hvor seerne bestemt ikke vil foretage valg. Det gælder f.eks. valg af forskellige slutninger på film, hvor det er meget signifikant, at det ønsker seerne ikke. Film har en original slutning forudbestemt af instruktøren, mens seernes egne (forskellige) valg anskues som uoriginale.

I argumentationen og begrundelserne for jordbaseret digitalt tv anvendes primært et teknologisk fokus, hvor teknologien er dét, som trækker udviklingen fremad. Det er imidlertid problematisk at se teknologi løsrevet fra andre faktorer. Digitalt terrestrisk tv har ingen værdi i sig selv, men har brug for et indhold, hvor nogle ønsker at bruge teknologien. TV2/Nord-Digital forsøget var i væsentlig grad præget af et teknologisk fokus, hvorfor de selvvalgte test-piloter primært havde en teknologisk motivation. Imidlertid var det også disse brugere, der var mest skuffede i forhold til det digitale tv. Det var derfor også denne teknologimotiverede brugergruppe, der udviste det største frafald af testpiloter under det nordjyske digitale tv-forsøg. De testpiloter, som havde haft en motivation i at se mere regionalt fjernsyn, var væsentlig mere tilfredse end de brugere, som havde en teknologisk motivation. Det var ligeledes signifikant, at det var manden, der var mest interesseret i TV2/NordDigital som teknologisk objekt i form af de interaktive tjenester. Derudover havde stueantennen i et æstetisk perspektiv afholdt nogle husstande fra at placere set-top-boksen i dagligstuen, som dermed også medførte en anden brug af kanalen.

Der var forskellige måder, hvorpå seerne gik ind i ekstrainformationerne fra TV2/Nord-Digital. Nogle gik ind i starten af programmet, andre mere situationsbestemt og andre igen mod slutningen af programmet. Der opstår imidlertid en række problemer i forhold til en kollektiv sening af digitalt interaktiv tv, når der skal foretages mange valg, fordi der kun er én person, der kan anvende fjernbetjeningen. Hvis der er flere, der sidder og ser det samme program, er de uden fjernbetjening blevet henvist til at være observatører og ikke-brugere af de interaktive tjenester. Derfor anvendes den digitale merværdi (tekstbaserede ekstrainformationer) oftere, når man sidder alene, frem for når man sidder flere og ser det samme. Det situerede praksisfællesskab omkring tv-seningen har stor betydning i forhold til, om der foretages solo- eller kollektivsening. I kraft af danske husstandes adgang til flere og flere tv-kanaler og øget antal tv-apparater i hjemmet går solo-seningen frem på bekostning af kollektivsening. Digitalt 
interaktivt tv kan både fremme flere individuelle valg og solo-seningen, men kan også øge det sociale praksisfællesskab og kollektivseningen omkring f.eks. interaktive quizzer. Solo- og kollektivsening afhænger således i høj grad af genren - og hvilken returvej der benyttes. De mange programmer der gør brug af mobiltelefonen som returvej (f.eks. quizzerne Hvem vil vere millionar og Deal-No-Deal), har derfor den store fordel, at her kan den enkelte seer stemme eller gætte med i et individuelt valg på egen mobiltelefon, og uden at skærmbilledet ændres på grund af interaktive valg. Baggrunden for den primære solosening af interaktive tjenester (fra f.eks. TV2/Nord-Digital) skyldes derimod, at der kan opstå nogle magtkampe i familien i forhold til fjernbetjeningen, og hvor skærmbilledet ændres radikalt i forhold til de valg den person med fjernbetjeningen måtte foretage. Mediebrugerne i hjemmene vil gerne være interaktive med deres fjernsyn - men på forskellige måder, på forskellige tidspunkter til forskellige genrer.

Medieudbuddet af tv er kendetegnet ved at være offentligt, i den forstand at det er produceret til at skulle modtages af mange. Mediebrugen af tv er derimod karakteriseret ved at blive modtaget af individer, og fortrinsvis i privatssfæren. Det synes at fremgå af den digitale fremtid, at mediebrugen i højere grad vil glide væk fra et fast kollektivt handlingsforløb i hverdagslivet (som f.eks. se Nyhederne kl. 19.00 sammen med ca. 800.000 andre danske i et her-og-nu). Mediebrugerne efterspørger i stigende grad, at de kan versionere hverdagslivet på deres måde (f.eks. via en PVR), så de opnår en fornemmelse af individualitet. At man f.eks. selv kan bestemme hvornår man ønsker at se Nyhederne, i forhold til mediebrugernes egen hverdagslivsstruktur. Således behøver man ikke længere indrette spisetiderne efter Nyhederne, men i den digitale fremtid må Nyhederne pænt indrette sig efter spisetiderne.

I forskningsmæssig sammenhæng mangler der stadig indsigter i et sociologisk perspektiv mellem hvordan hverdagsliv og interaktive tjenester hænger sammen. Der mangler således indsigter i om vores hverdagsliv forandres i takt med den stigende digitalisering, og i så fald hvorfor og hvordan? Særligt mangler der et forskningsmæssigt fokus på brug og oplevelse af et konkret interaktivt indhold (selve teksten- og tekstoplevelsen) i et mikrosocialt perspektiv. Jeg beskriver kort i artiklen hvordan interaktivt indhold også kan øge det sociale praksisfællesskab og kollektivseningen omkring f.eks. interaktive quizzer. Det kræver dog større studier at fastlægge hvordan det sociale praksisfællesskab omkring et interaktiv indhold etableres og fungerer, herunder hvilke elementer der gør at seerne vil samles eller ikke vil samles kollektivt og gætte med i f.eks. diverse quizzer, afstemninger eller foretage kameravalg.

\section{Referencer:}

Bjørner, T. (2005). Interactive television - is it egocentric television for the man in the household?. In Jensen, J. F. (Edt.), User-Centred ITV Systems, Programmes and Applications (pp. 93-97). Proceedings EuroITV 2005: InDiMedia, Aalborg University.

Eronen, L. (2005). User Centered Research Methods for Interactive Television. In Jensen, J. F. (Edt.), User-Centred ITV Systems, Programmes and Applications (pp. 15-26). Proceedings EuroITV 2005: InDiMedia, Aalborg University.

Gallup TV-Meter (2004).

Helle-Valle, J. \& Stø, E. (2002, September 13). Digital TV and the moral economy of the home. Paper at the Seminar: Digi-tv -television as a consumer platform, Faroe Islands.

Higgins, M. (2000). Divergent Messages in a converging World. The Information Society, 16, 49-63.

Jennings, R.U. et al. (2004, March 1). Interactive Digital spreads Its European Wings. Forrester Research.

Looms , P.O. (2004). Digitalt interaktivt tv i Europa: Hvor vigtig er interaktivitet?. In Holmgaard Christensen, L. (Red.), Interaktivt to...vent venligst...-11 bidrag til forståelsen af to's digitale mervardi: Aalborg Universitetsforlag.

Mackay, H. (2002). Transformations in Media Consumption: an Ethnography of Radio, Television and new media in Everyday Life in Wales. Paper for COST A20 Networdk conference: The Impact of the Internet on the Mass Media 21-22. June 2002, Tromso.

Morley, D. (1986). Family Televison - Cultural Power and Domestic Leisure. London: Comedia.

O’Brien, J.R., Rouncefield, M. \& Hughes, J. (1999). At home with the Technology. An ethnographic Study of a Set-Top-Box Trial. ACM Transactions on Computer-Human Interaction, Vol. 6, No. 3.

OFTEL (2001). Digital Television - Consumers' Use and Perceptions. Counterpoint Research: OFTEL.

Rasmussen, T.A. (2002). To og internet I hjemlig brug. Aalborg Universitet: Institut for Kommunikation og VR Medialab.

Theodoropoulou, V. (2003). Consumer Convergence -Digital Television and the Early Interactive Audience in the UK. In Lowe, F. \& Hujanen, T. (Eds.), Broadcasting E Convergence: New Articualations of the Public Service Remi". Göteborg University: Nordicom. 
TDC (2003). Selector Tracking - december 2003.

TV2/Nord-Digital (2004). Statusrapport, efteråret 2004. Zerlang, M. (2003). Midt i en quiz-tid. In Jensen, J. F. (Red.), Analyser af tv- og tv-kultur. København: Medusa.

Thomas Bjørner er adjunkt ved Medieteknologi og Ingeniørvidenskab på Aalborg Universitet

\section{Noter}

1 DTT står for Digitalt Terrestrisk TV, og betyder at signalet er jordbaseret dvs. via sendemaster, og skal ses i modsætning til distributionsformer som kabel- og satellit.

2 Den kvalitative del var baseret på gruppeinterviews af 15 husstande. Husstandene blev interviewet over to omgange, et i starten af forsøget (november/ december 2002) og et mod slutningen (december 2003). I forbindelse med interviewene blev der foretaget en fotoserie af husstandens medieapparater, i forhold til hvor de havde valgt at placere deres set-top-boks. Derudover blev der foretaget tre fokusgruppeinterview. Den kvantitative del bestod i udsendte spørgeskemaer til samtlige test-piloter: I første runde var der udsendt 265 spørgeskemaer via brevpost, heraf 157 besvarelser og $\mathrm{i}$ anden runde var der udsendt 176 elektroniske spørgeskemaer, heraf 91 besvarelser. Derudover blev seerne bedt om at udfylde en elektronisk dagbog, hvor de registrerede hvem der havde set programmerne, hvor meget de havde set, om de havde brugt den digitale merværdi og en vurdering af programmerne. Endelig modtog TV2/Nord-Digital en lang række e-mails med kommentarer og vurderinger, som også indgik i det empiriske forskningsmateriale.

3 Det Digitale Nordjylland var et regeringsinitiativ fra 2000, hvor Nordjylland blev udvalgt til at etablere det ene af to IT-fyrtårne i landet (Ørestaden var det andet) for at fremme IT-udviklingen og brugen heraf. Visionen var at skabe de første netværkssamfund. Det Digitale Nordjylland indebar 89 forskellige projekter, som repræsenterede en værdi af mere end 80 millioner Euro.

4 Interviewhusstande var for det første inddelt efter følgende alderskriterier, hvor jeg har angivet antallet af deltagende husstande i parentes: 18-29 år (4 husstande), 30-54 år (7 husstande) og 55+ (4 husstande). For det andet var husstandene inddelt efter antal medlemmer $\mathrm{i}$ husstanden (varierende fra 1-4 personer). For det tredje var kriteriet en variation af hhv. urban og ikke urban placerede husstande.

5 Programoversigten er i øvrigt de sider på tekst-tv der benyttes hyppigst, nummer to på hitlisten er nyheder, 3. programomtaler, 4. vejret og 5. sporten (DR Medieforskningen, 1. halvår 2005).

6 Der er dog intet der forhindrer de enkelte husstande i at sætte set-top-boksen til et andet fjernsyn efter installering. 